\title{
USE OF COMPUTER TECHNOLOGY COMPETENCIES AT THE FOREIGN LANGUAGE LESSONS
}

\begin{abstract}
Summary. The article is devoted to the problem of using modern information technologies in educational process of higher educational establishments. Teaching of foreign languages and using software products (computer presentation, website and tests) are under consideration. This article is concerned with the problem of using of the modern educational technologies in education in general and in English learning, the concepts of innovative pedagogical technologies, their advantages in education, introduction of computer technologies and their role in foreign languages teaching. It gives a brief description and characterization of innovative pedagogical technologies in English teaching. It is described how the use of information and communication technologies allows us to organize the learning process and what are the main tasks of using teachers of information and computer technologies can be highlighted. The main advantages of these technologies, which consist in the fact that they allow to inform the teaching process, more in line with the requirements of the modern school in comparison with the classroom model are substantiated. The objectives of such training are based on the potential of the computer as a means of cognitive-research activities, provide a person-oriented approach to learning that promotes the development of individual abilities of students.
\end{abstract}

Keywords: computer technologies, software products, innovative educational technology, informatization, information and computer technologies, individual abilities, project, Internet, foreign languages.

Купар M.C. Національний університет «Полтавська політехніка імені Юрія Кондратюка»

\section{ВИКОРИСТАННЯ ІНФОРМАЦІЙНО-КОМП'ЮТЕРНИХ ТЕХНОЛОГІЙ НА ЗАНЯТТЯХ 3 ІНОЗЕМНОЇ МОВИ}

\begin{abstract}
Анотація. Стаття присвячена дослідженню проблеми використання сучасних інформаційних технологій у закладах вищої освіти. Вивчаеться питання викладання іноземних мов з використанням комп'ютерних технологій та використання програмних продуктів (комп'ютерна презентація, веб-сайт, тести тощо). У статті порушено питання: використання сучасних педагогічних технологій у навчанні англійської мови, впровадження комп'ютерних технологій та їх роль при вивченні іноземних мов. Подається короткий опис та характеристика інформаційних технологій у процесі викладання англійської мови. У статті обтрунтовані головні переваги даних технологій, які полягають у тому, що вони дозволяють інформатизувати начальний процес, більше відповідають вимогам часу у порівнянні зі стандартною моделлю ведення заняття. Цілі такого навчання спираються на потенційні можливості комп'ютера як засобу пізнавально-дослідницької діяльності, забезпечують особистісно-орієнтований підхід до навчання, що сприяє розвитку індивідуальних здібностей студентів. Викладачі закладів загальної середньої освіти, і, що ще важливіше, викладачі закладів вищої освіти та фрахової передвищої освіти повинні розвивати навички, які дозволять їм використовувати комп'ютер як навчальний ресурс для покращення навчання учнів та студентів й підготувати їх до легкого вступу та утвердження себе у високотехнологічному суспільстві, у якому вони щоденно стикатимуться з різними викликами, ставлення та навички. Для цього програми навчання вчителів та підвищення кваліфікації для вчителів-практикуючих повинні зосередити увагу на забезпеченні розуміння застосування комп'ютерних знань, а також основних та більш досконалих навичок, пов'язаних із володінням комп'ютером. Автори наголошують, що використання комп'ютерних технологій у навчальному процесі дає змогу збагатити навчальний процес шляхом створення комп'ютерних презентацій, публікацій, окремих сайтів, що містять повну інформацію про вивчене за різними темами. Це допомагає зробити іноземний мову гнучким інструментом для спілкування, надаючи можливість розширити словниковий запас та полегшити розуміння.
\end{abstract}

Ключові слова: компютерні технології, програмне забезпечення, інноваційні педагогічні технології, інформатизація, інформаційно-компютерні технології, індивідуальні здібності, проект, інтернет, іноземні мови.

Target setting. The importance of technol1 ogy in our everyday and academic lives is increasing. Technology has become a powerful catalyst in promoting learning, communications, and life skills for economic survival in today's world [1]. The problem of new technologies and corresponding methods of teaching is considered to be one of the topical ones. Much depends on the learning resources used at the lesson which help students to master the language versatility.

It is commonly known, that the main purpose of the language is to establish and develop a culture of communication, so the primary aim is enabling the students to use the language to express their opinions and share their ideas and feelings. The communicative strategy of language learning logically determinates the new requirements to reading and listening, topic arrangement, grammar and communicative performance. In this respect the key to successful learning might be connected with numerous technologies used to achieve the expected result. Nowadays Ukraine puts right the relationships of new character with the countries of the whole world, and it is necessary to admit a rather important step is adjusting of contacts with the USA, Great Britain, Canada and other English-speaking 
countries. Modern look at English as at specific intellectual activity aims adding to students' arsenal methods and adopting pedagogical activity, which forms a creative personality in the process of this activity. For this reason, the problems of method of teaching of foreign languages seem especially authentic nowadays.

Actual scientific researches and issues analysis. Modern stage of society development is so "overinformed", that it requires certain reforms in sphere of education, expansion of subjects of information offered to the students. Gradually the personality oriented system of teaching became used instead of the traditional one. Traditional methods are changed for innovative ones. Consequently, there is displacement of accents in teaching, when a situation is of such a kind that attaining of high-quality indexes without introduction in the educational process of computer technologies seems to be just impossible. This problem is considered to be of great interest and it is being explored by numerous scientists, research workers, methodologists, teachers and students very attentively. Principles of application of modern information technologies at the lessons of foreign language were examined in works of such researchers as, P. Kapitonov, L. Konstantinova, M.Korsakova, E. Muzlanova, Y. Romanenko, V. Trainev and others.

Highlighting components of the scientific problem, which have not been solved before. However, there are no such concrete sources which could include as far as possible complete information on this theme. These major and urgent challenges for the integration of technology in the classroom are interpreted by the Ukrainian educational authorities in the way which emphasizes the necessity of the hardware supply for educational establishments. This is currently leading to the situation in which many schools and most universities are packed with computers, but very few of them are being effectively used in student learning since the majority of university and schoolteachers lack at least basic computer competencies.

The research objective. In the given article we will consider the computer technologies, that can be used in a teaching and educational process for the increase of his efficiency and intellectual development of students. Some program means can help a teacher to develop general educational and special skills at the English lessons in the students, and also skills of thought of high level considerably quick and more effectively than while using of traditional means.

Presentation of basic material of the research. In the process of study there is constantly a question about approaching of one subject to another and about collaboration of pedagogical stuff, which is concentrated upon forming ordinary student as conscious and intellectual personality. An educational project, as well as organizational form of work, is orientated on mastering of educational theme or educational section and makes part of standard educational object or a few objects. At school this form of work can be examined as joint educational-cognitive, research, creative or playing activity (individual, pair, group), obtaining the general purpose. Teachers apply those methods and ways of activity, which are directed on achieving a general result, necessary for the decision of the put problem. Application of new forms of studies gives a possibility to extend the limits of creative activity of both a teacher and students, realize facilities of effective application of computer technologies during the study of different objects, to teach students to independent research activity during the decision of the practically directed tasks. According to the aforesaid, it should be confessed, that the major constituent of teaching process is not computers, but teachers who are able to own the methods of the use of information technologies. Using in an educational process multimedia presentations, publications and web sites, created by a teacher gives a possibility to develop students' ability to formulate their opinions clearly, to approach to solving the problems and given tasks creatively. In addition, application of computer programs and other products in the educational process enables communication with a wide audience. Listening comprehension is an extremely important skill because people spend nearly half of their communication time listening. There are many benefits to use video for foreign language listening comprehension [2, p. 14].

Perhaps the most important is that video clip provides sufficient context and the learner can take the advantage of using the background knowledge to the maximum. Personal involvement of the students helps to enhance stimulating and challenging activities, encouraging the learners to share their ideas in response to the video information used. It is also an effective way to master writing habits as students give written retelling of video fragment, make dialogues based on it, ask questions on the context. Another advantage of using video is its contextualization. Video breaks the monotony of the classroom routine, giving us the best framework for remembering as compared to audiotapes; it promotes mastering the language on phonetic, lexical and grammatical levels; it relates the material under study to personal experiences of the students; video provides an access to many situations which are difficult to recreate in the classroom including historical, educational and cultural background. Among the advantages is the fact that at any moment you can stop the film and come back to the place you think is worth watching again. While selecting video the following important factors should be taken into consideration: video characteristics, language characteristics, learners' characteristics. Video characteristics: each video product used at the lesson should be connected with the topic and it should have a set of necessary characteristics among which clear-up image; the segment should not be dubbed and use subtitles if the goal is to enhance listening skills. It is essential to select short segments to facilitate listening because learners have limited memory capacity in foreign languages. Language characteristics of video fragment used in the classroom are very important as well. Language characteristics include such aspects: speech delivery, fluency of language, presence of recognizable words, phrases, phraseological units. Learners' characteristics include age, sex, interests, proficiency level, social environment [3, p. 21-24]. British scientists K. Finger, C. Stone, T. Casert proved that video method of language learning reduces up 
to $30 \%$ of the time required to learn the new words. This is facilitated by a variety of factors, the most significant of which is a synchronous operation left (mainly responsible for the decoding of visual signals) and the right (focusing on the perception of the same meaning of the sounds, pauses, emphases etc.) brain hemispheres. This allows more acceptable level of knowledge as a supportive reception of memory. It is considerable to stress that general steps to take before the presentation of the video information are: selecting appropriate materials; structuring the materials in accordance with the tasks; outlining the techniques and tasks to use at different stages of its presentation. Most dramatic presentations are calculated to create a feeling and reaction in the audience to characters and situations. Move beyond fact-finding in your questions. Put the students in the drama and ask how they would have felt when certain things happened.

The developing electronic communication networks offer the prospect of more rapid and convenient exchanges. There has been comparatively little formal developmental work carried out by Ukrainian education authorities. Although the Ministry of Education and Science of Ukraine constantly is declaring the uttermost priority of computerization processes in the educational system (National Doctrine of the Education Development in Ukraine, adopted by the Decree of the President of Ukraine, № 347/2002, April 17, 2002; State Program «The Teacher", adopted by the Decree of the Cabinet of Ministers of Ukraine № 379, March 28,2002), these priorities are either left in the form of declarations or to be realized and applied somehow. Teacher Education programs include the courses of learning computer technologies, but they are of very little help to supply future teachers with proper skills of using a computer in their professional activities (they just help students to become mere users of a PC without taking into account the needs of future teachers). The inequitable distribution of the technologies poses real equity problems in the delivery of the curriculum. Thus there is a concern that some students are missing out on the new basic computer literacy and proficiency skills. Most teachers need time and special methodology (which is still not available in the present Ukrainian methodological and teacher education science, and which is being investigated and developed by the author of this article), well developed programs to enable them to become expert with the technology. And as the importance of information technology has been generally recognized by teachers, they have been largely expected to learn computer competencies for their professional activities by themselves, or informally through their colleagues, and usually at their own expense.

It also often occurs that students have access to more sophisticated technology for longer periods than their teachers and the students as experts can undermine the self-esteem of teachers. There are also indications in the Ukrainian educational experiences that some teachers feel that they have been left behind by the rapidity of the expansion and development of new technologies. So there is a need for a major professional development methodology: it will empower teachers to become confident, critical and creative users of all of the new developments in information technology and capable of using them in a teacher's professional activities. We emphasize the need for an overall professional development strategy rather than existing fragmentations. The summary of the analyzed scientific resources and our own teacher training experiences suggest that this strategy should include three stages:

1) basic computer literacy skills, which will enable school administrations to unite all teachers under one and the same starting level of using computer technologies in their professional activities;

2) personal and professional use of technology;

3) application of technology in instruction teacher's computer competencies necessary for creation a professionally competent teacher with wide range of capabilities of systematic integration of computer technologies across the curriculum.

Having developed the proper competencies at the first stage the teachers will be able to: use computer systems - run software; access, generate and manipulate data; publish results. They will also evaluate performance of hardware and software components of computer systems and apply basic troubleshooting strategies as needed. The set of tasks to show adequate competencies at this stage includes: operate a multimedia computer system with related peripheral devices to successfully install and use a variety of software packages; use terminology related to computers and technology appropriately in written and oral communications; describe and implement basic troubleshooting techniques for multimedia computer systems with related peripheral devices; use imaging devices such as scanners, digital cameras, and/or video cameras with computer systems and software; demonstrate knowledge of uses of computers and technology in business, industry, and society.

The teachers will apply tools for enhancing their own professional growth and productivity. They will use technology in communicating, collaborating, conducting research, and solving problems. In addition, they will plan and participate in activities that encourage lifelong learning and will promote equitable, ethical, and legal use of computer/ technology resources. The set of tasks to show adequate competencies at this stage includes use productivity tools for word processing, database management, and spreadsheet applications; apply productivity tools for creating multimedia presentations; use computer - based technologies including telecommunications to access information and enhance personal and professional productivity.

The teachers should be able to apply computers and related technologies to support instruction in their grade level and subject areas. They must plan and deliver instructional units that integrate a variety of software, applications, and learning tools. Lessons developed must reflect effective grouping and assessment strategies for diverse populations. The set of tasks to show adequate competencies includes: explore, evaluate, and use computer resources including applications, tools, educational software, and associated documentation; describe current instructional principles, research, and appropriate assessment practices as related to the use of computers and technology resources in the curriculum; design, deliver, and assess student learning activities that integrate computers for a variety 
of student group strategies and for diverse student populations; design student learning activities that foster equitable, ethical, and legal use of technology by students; practice responsible, ethical and legal use of technology, information, and software resources. We also presume that such strategy should empower students with the following elements of computer competencies for professional use: the skills of searching and processing information; the skills for evaluation of existing educational computer programs; the skills of using computer technologies in presenting the learning material, teaching strategies and classroom management; the skills of using computer technologies in assessment of student's learning achievements, computer testing.
Conclusions and propositions. Thus, the use of computer technologies in the educational process enables to enrich a curriculum by creation of computer presentations, publications, separate sites contained complete information on the studied at different themes. Video actually helps to make the foreign language flexible tool for communication providing an opportunity to expand vocabulary participants and facilitating understanding. Work of students with the computer programs makes it possible to get profound knowledge, oriented on the search and acquisition of a new experience, cognition of computer and application of studied information in everyday life.

\section{References:}

1. Kenneth L. Everson (2005). Teaching English Using Video. English Language and Culture. Vol. 3, pp. 2-8.

2. Blake J. (2000). Improve your Listening Comprehension. Profile. Vol. 3, pp. 12-16.

3. Finger K., Stone C. (2000). Video at the Lessons. Reflections of Learning and Teaching. The British Council-Dinternal, pp. 47-68.

4. Kay J. J., Mellar H. G. (1994). Information Technology and New Primary School Teachers. Journal of Computer Assisted Learning. Vol. 10, pp. 157-167.

5. Mackowiak K. (1991). The Effects of Faculty Characteristics on Computer Applications in Instruction. Journal of Research on Computing. Vol. 23, pp. 396-410.

\section{Список літератури:}

1. Kenneth L. Everson. Teaching English Using Video. English Language and Culture. 2005. Vol. 3, pp. 2-8.

2. Blake J. Improve your Listening Comprehension. Profile. 2000. Vol. 3, pp. 12-16.

3. Finger K., Stone C. Video at the Lessons. Reflections of Learning and Teaching. The British Council-Dinternal. 2000, pp. 47-68.

4. Kay J. J., Mellar H. G.. Information Technology and New Primary School Teachers. Journal of Computer Assisted Learning. 1994. Vol. 10, pp. 157-167.

5. Mackowiak K.. The Effects of Faculty Characteristics on Computer Applications in Instruction. Journal of Research on Computing. 1991. Vol. 23, pp. 396-410. 